\title{
The problems existing in the development of the modern Jingdezhen ceramic education
}

\author{
XiuMei Wu \\ University of Jingdezhen ceramic institute of design art
}

Keywords: Jingdezhen, modern ceramic education, problems.

\begin{abstract}
Jingdezhen ceramic art as a long history of traditional craftsmanship is always to the father the son in China, and ways of division. But since the early years of the republic of China the development of capitalist economy, the introduction of foreign advanced machinery and technology, the emergence of a new mode of production, there is a lot of can adapt mechanization production workers. Therefore, traditional father and son, ACTS on division skill inheritance patterns, he gradually won't work, since the end of generation is the new education mode to develop ceramic technology talents, pottery and porcelain of the establishment of vocational schools is catered to the new talents training mode, that is the preliminary of Jingdezhen ceramic education reform. Anything have to undergo a long process of reform, the reform is hard, to pay the blood of generations, Jingdezhen ceramic education the tortuous, migration, merged and renamed constantly change, for the modern Jingdezhen ceramic education guiding ideology, there can be no a complete so in all kinds of resistance and economic pressure to become their own ways, result in ceramic art inheritance of inadaptability.
\end{abstract}

\section{Imperfect Education System}

School, Jingdezhen (ability of Chinese contented industry (hereinafter referred to as the Tao school), is the city one of the earliest a ceramic professional school, initiated by Zhang Hao and Kangda, joint straight Di (now Hebei), Hubei, Anhui, Jiangxi four provinces, to Xuantong three years (1911), first President Zhang Hao. Zhang Hao, Jiangxi new person (because of his father in Yunnan province as a municipal department, people mistakenly say people in Yunnan province), is one of the earliest foreign students to Japan to learn ceramics and back home, to have the revitalization of industry, reform the ambition of ceramic industry, in practice. Indeed, made contribution for ceramic production technology advancing, so future generations often said he is open to the development of modern industry production. In 1912, the school changed to Jiangxi, ability of Chinese contented industry, Jiangxi Rao state contented industry school, four years of the republic of China (1915), according to education ministry make, renamed the dimethyl industrial school in Jiangxi province, the campus is its "affiliated b industrial school". Twelve years of the republic of China (1923), Tao school and renamed Jiangxi porcelain industry school, Jingdezhen, for campus. Sixteen years of the republic of China (1927) spring, with the approval of the provincial government, pottery, including Jiangxi Jingdezhen contented industry school, quasi distribution headquarters migration also, in the same year autumn, changed its name to a contented industry school in Jiangxi province.

From the top, you can see that Tao changed several times in the school, campus has never stopped, education in an unstable state, and the education all over the country are based on earlier, not a perfect education system for reference, Jingdezhen ceramic education is imperfect in system, can only be groping in reform. Cause the reason is mainly as follows: first of all, the lack of management experience and capital; Second, due to historical reasons, Jingdezhen ceramic production process, whether maintain clinkering, or main production process or in a manual operation, or more primitive, the introduction of new technology for a long time in the period of rejection. Finally, combined with the father the son, the traditional thought of vocational education is difficult to get social trust and support, the school education system and reform of the 
implementation of the resistance is very large, although Zhang Hao and so on a number of people advocate and promote but also out of puff, unable to break through. In Japan, Zhang Hao, machinery manufacture, mines clinkering, Jingdezhen ceramics production conformism, feudal gangs are serious, "Oriental" porcelain making technology, cannot place in Jingdezhen, so, tao school site in Jiang Xirao states (the float saddle when spare capital halls, and after several migrations is untenable, more don't talk about the improvement of the education system.

To sum up, the modern Jingdezhen ceramic education guiding ideology, there can be no a complete in all kinds of resistance and economic pressure to become their own ways.

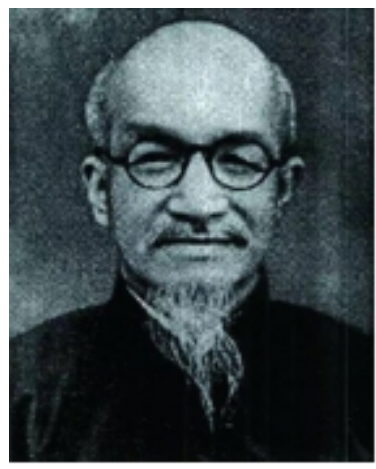

Figure 1 Zhang Hao Photo “porcelain nets”

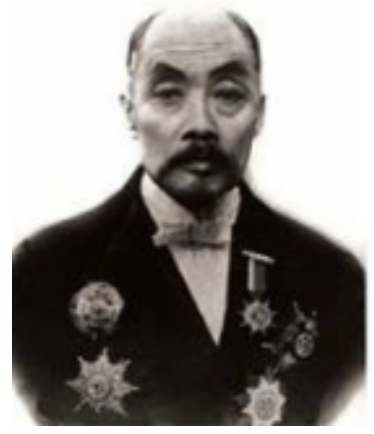

Figure 2 Zhang jian Photo“porcelain nets”

At the beginning of the modern, the traditional handmade porcelain art heritage and modern ceramic education inclusions formed two development route, folk ceramic art inheritance and official ceramic art inheritance, form a mix between them, however, ceramic school on education of students in ceramic art inheritance pattern also mix the hired master of folk ceramic art inheritance, the blend mode of education, the main reason is that society has not yet universal basic education sense at the time, didn't regard education as a professional, thought that everyone has a skill is the expert. Should from the reality, around that time still lack basic education standards, the basis of professional education is a blank for ceramics.

Mix of education also reflected in the following aspects: first, in the blend of Chinese and western education concept. Western education philosophy and Chinese traditional Confucian concept of education, and part of patriots advocated reform traditional education idea of insight, the three form a mix, repel each other, and absorb each other. Western education advocates the combination of education and science and technology, advocate equality between men and women to accept education, everyone has the right to enjoy education. Kang Youwei is first put forward the intellectual education in modern China, and feeling, idea education pay equal attention to education policy. He thinks, the human mind, intelligence and emotion, is with three parts, he pays attention to the cultivation of learning ability, attach importance to moral education, namely the new morals of the bourgeoisie, to social morality as the main body of a new kind of conduct education students to do has the tutelage, has a perfect moral man, do valuable modern people, therefore, Liang Qichao also pay attention to the cultivation of ability and personality. Women they have to accept education is good for you to manage, and super firmly opposed to the traditional concept of innocence is the 
virtue for women, he said: "this is the way of the evil world." Initiative, women should be out of their homes, become "practice", by learning that can change the poverty of the family, can change women attached to the present situation of the male, more independent economic status, knowledge to improve, is women's own liberation and equality between men and women. In certain talent instinct without difference between men and women, to encourage women to know their own advantages, set up the confidence, even surpass men in some ways, often a man is not poor qualities, women and the poor man cannot create the law, and the woman of gen. The traditional Confucian education concept is the woman to obey the wifely submission and virtue, when women learn is, etc. These mixes of education thought that when mixed with ceramic education mode, it is difficult to define is what kind of fixed mode of education should be taken to design the system of education. Secondly, the mix of Chinese and western education mode. Western education mode setting requirements for courses in every subject learning courses, pay attention to curriculum and course direct connectivity, such as western-style school subjects such as math, science, medicine, biology, engineering drawing course is required. Therefore, Jingdezhen ceramic education not only include a picture, and math, science, engineering and other subjects. Due to the influence of traditional Confucian culture, of course, the students in the school and learning the traditional Confucian culture.

So relatively closed at the time of Jingdezhen, the part advocate saving country through education, through the education to save the complete collapse of porcelain, the western returned the young students want to through the western education system to completely change the backward education of pottery and porcelain, and feudal and traditional folk advocates tutorial system formed two kinds of education mode.

\section{Conclusion}

To sum up, Jingdezhen ceramic art as a long history of traditional craftsmanship is always to the father the son in China, and ways of division. But since the early years of the republic of China the development of capitalist economy, the introduction of foreign advanced machinery and technology, the emergence of a new mode of production, there is a lot of can adapt mechanization production workers. Therefore, traditional father and son, ACTS on division skill inheritance patterns, he gradually won't work, since the end of generation is the new education mode to develop ceramic technology talents, pottery and porcelain of the establishment of vocational schools is catered to the new talents training mode, that is the preliminary of Jingdezhen ceramic education reform. Anything have to undergo a long process of reform, the reform is hard, to pay the blood of generations, Jingdezhen ceramic education the tortuous, migration, merged and renamed constantly change, finally contented industry in 1947, the school upgraded to a junior college, upgrade contented industry of the development of the college by the east wind up development, those who oppose the school's conservatives have to admit that the advantages of ceramic school during this ceramic school not only successfully designed the Chiang Kai-shek's gift porcelain, have successfully made the queen's wedding gift porcelain, these gift porcelain production for contented industry laid the foundation of the school development.

\section{Acknowledgements}

Xiu-mei Wu, female, doctor of design art, in Fuzhou, master instructor, research direction: the art of design principle, industrial design and theory, ceramic art design and theory.

This paper is the Jingdezhen ceramics university canter for collaborative project: "Jingdezhen ceramic art education from the evolution of modern times to contemporary".

\section{References}

[1] Xiu-mei Wu: The evolution of the Jingdezhen ceramic education from modern times to the modern, nanchan, Jiangxi fine arts publishing house, 2016.11. 
[2] Xiu-mei Wu: the inheritance and change - Jingdezhen porcelain development research of the republic of China, Beijing, guangming daily press, 2012, 5.

[3] Xiu-mei Wu: the traditional handicraft culture research - ceramic hangzhou fan, for example, Beijing: guangming daily press, 2013, 5.

[4] Zhen-fan Wan, Lin Songhua editor: studies of modern times social transformation in Jiangxi, Beijing: China social sciences press, 2001.

[5] Xi Chuan performance: "the classical works of design art anthology, nanjing: southeast university press, 2002. 